SOCIETY AND SOCIAL POLICY:

THEORETICAL PERSPECTIVES

ON WELFARE 


\title{
Society and Social Policy: Theoretical Perspectives on Welfare
}

\author{
RAMESH MISHRA \\ Department of Social Studies, \\ Portsmouth Polytechnic
}

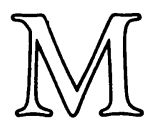


(c) Ramesh Mishra 1977

Softcover reprint of the hardcover 1st edition 1977 978-0-333-21504-3

All rights reserved. No part of this publication may be reproduced or transmitted, in any form or by any means, without permission.

First published 1977 by

THE MACMILLAN PRESS LTD

London and Basingstoke

Associated companies in Delhi Dublin

Hong Kong Johannesburg Lagos Melbourne

New York Singapore and Tokyo

ISBN 978-0-333-21505-0 ISBN 978-1-349-86139-2 (eBook)

DOI 10.1007/978-1-349-86139-2

This book is sold subject to the standard

conditions of the Net Book Agreement

The paperback edition of this book is sold subject to the condition that it shall not, by way of trade or otherwise, be lent, resold, hired out, or otherwise circulated without the publisher's prior consent in any form of binding or cover other than that in which it is published and without a similar condition including this condition being imposed on the subsequent purchaser. 
To E. H. Crawford 


\section{Contents}

Introduction

ix

PART 1 APPROACHES TO WELFARE

1 The Empirical School: Social Administration 3

2 Welfare as Citizenship 20

3 Convergence Theory or Technological Determinism: Welfare System as a Product of Industrialism 33

4 The Functionalist View 43

5 The Marxist Perspective 61

PART 2 SOCIAL STRUCTURE AND WELFARE From Theory to Application: a Postscript and a Preface

6 Capitalist Society and Social Welfare

7 Welfare in Socialist Society: 'To Each According to His Needs'?

Concluding Remarks

Notes and References 


\section{Introduction}

Three basic beliefs underlie this book. Firstly, that theory matters, and that the study of social policy should be grounded far more firmly in social theory than is the case at present. Second, that a cross-national and generalising approach is necessary to throw light on the nature and development of social policy in particular national contexts. Third, that in order to understand the problems of social policy adequately and to contribute to their solution it is necessary to understand the wider social context of policy. In short, an appreciation of the complex relationship between society and social policy - the major focus of this book - is vital for the student of policy. But this relationship is not something self-evident or given. Social scientists hold differing views about the nature of society as well as of social policy and about their inter-relationship. Part 1 of the book examines five such major viewpoints or perspectives. Part 2 looks at the nature, development and consequences of social policy in the context of the two main types of industrial society - capitalist and socialist. The insights gained from Part 1 are used here to explore the relation between types of social structure and social policy. A final chapter draws some of the themes from the two parts together by way of conclusion.

Perhaps a word needs to be said about the approach in Part 2. To those accustomed to the study of social policy of a particular country in depth it may seem preposterous to generalise about dozens of capitalist countries (what is more, all in the space of a chapter) which differ from one another in significant ways and about whose social policies foreign nationals have, at best, scanty knowledge. The same criticism applies, with perhaps greater force, to the discussion about socialist countries. True, the treatment of the subject matter in these chapters is extremely schematic; it is also necessarily tentative. On the 
other hand, the view that generalisations cannot be made until an exhaustive body of data has been accumulated seems to me both unrealistic and mistaken. Firstly, we may never be able to reach the ideal state of affairs concerning data. Second, and more important, the work of generalising, 'model-building', theorising and so on must go hand in hand with the accumulation of facts. Indeed, one cannot even gather facts meaningfully without having some sort of a theory (however implicit) or general idea of what to look for. The important point, then, is not to shy away from generalisations but to treat them as working hypotheses which need to be tested against evidence. The material in Part 2 should be seen largely in these terms.

So far we have used the term social policy without really defining it. What exactly is our field of inquiry? Social policy can be defined in relatively narrow or wide terms. There is nothing intrinsically right or wrong about such definitions except that the definition adopted should be appropriate to the task in hand. The concerns of this book - for example, the examination of theories of the relation between society and social policy - demand a broad definition of the subject matter. As used here the term refers, in a generic sense, to the aims and objectives of social action concerning needs as well as to the structural patterns or arrangements through which needs are met. Our definition is not restricted to government action and arrangements concerning needs (we use the term social services for this) nor indeed to the context of industrial societies. Perhaps some such term as the institution of welfare or welfare policy expresses our meaning better. Indeed, in this book the terms welfare and social welfare have been used more or less interchangeably with the term social policy throughout. The reasons for this are not only stylistic. In pre-industrial - for example, tribal societies needs may be met largely through traditional rules of reciprocity. These arrangements have broadly the same end in view as social policy in industrial societies. But clearly the term policy, which suggests a deliberateness and a rational matching of ends and means, would be inappropriate in this context: welfare seems more apt. But this is largely a question of the appropriate term. More important, and perhaps open to objection, is the broad (and hence somewhat elusive) view of social policy adopted here. One reason for this is that too specific a view of the subject matter carries the risk of excluding certain relevant perspectives altogether simply by virtue of definition. In a book concerned with differing approaches to social policy we natural- 
ly wish to avoid this, preferring to err on the side of a wide rather than a narrow definition. Briefly, then, our interest lies in those social arrangements, patterns and mechanisms that are typically concerned with the distribution of resources in accordance with some criterion of need. We cannot be more specific than this since one of the main aims of the book is to look at the nature and meaning of welfare within a wide societal perspective. Thus the notion of welfare used here is more akin to broad social categories like religion, education, kinship or politics than to specific social organisations like the social services. The student of welfare cannot equate his subject matter with government policy in Britain any more than, say, the student of religion can equate his with the problems and policies of the Church of England. However, if in this respect the approach adopted here is unconventional in another respect it is fully conformist. (It did not seem either desirable or practicable to break away from tradition altogether.) Thus our discussion often centres around those needs and services (education, health, income security and housing but not transport, gas, electricity and so on) that have come to be recognised as the subject matter of social policy. This is particularly true of Part 2 of the book, which is empirical and focused on the social services.

Lastly, a word about the disciplinary orientation of this book: it is sociological. To say this is to warn the lay reader about jargon: it has been kept to a minimum. But a sociological text (let alone a psychology or economics text for undergraduates) cannot be expected to read like a novel - written in 'plain' English. Concepts are necessary for the understanding of social reality whose complexity cannot be adequately expressed in everyday language. Sociology, like economics, history, philosophy and others, is one of the many disciplines that contribute (or should contribute) to the study of social policy. What is offered here is one such contribution. The relevance of this book to the practical issues of policy is of course indirect. I hope this will not deter the practically minded student from looking at the relation between policy and society. I hope too that the book will stimulate the sociologists' interest in social policy. Indeed, it is also meant as a bridge between sociology and social administration in the belief that more traffic should flow in both directions between these two territories. 